\title{
Trade Competition and Environmental Regulations: Domestic Political Constraints and Issue Visibility
}

\author{
Xun Cao Penn State University \\ Aseem Prakash University of Washington
}

\begin{abstract}
How do domestic political institutions, specifically veto players, mediate the effect of trade competition on regulatory races in the environmental area? Is the mediating effect more pronounced for more visible pollution issues such as air pollution in relation to less visible water pollution? Governments are expected to respond to trade pressures by lowering regulatory costs. To do so, governments can rewrite regulations (de jure policy change) and/or lower the enforcement of existing regulations (de facto policy change). In contrast with de facto changes, de jure policy changes are more likely to invite opposition from pro-environment constituencies, and are therefore politically more difficult. Our analysis of 140 countries for the period 1980-2003 suggests that in response to trade pressures, governments do not lower regulatory stringency by rewriting (de jure) environmental regulations for any level of domestic constraints. In contrast, when political constraints are low, governments respond to trade pressures by adjusting regulatory stringency via de facto changes. Moreover, in the context of de facto policy changes, the constraining effect of veto players is more pronounced for air pollution (sulphur dioxide) in comparison to water pollution (biochemical oxygen demand). This is because air pollution is a more visible pollution issue around which organized, urban constituencies tend to mobilize.
\end{abstract}

T his article examines how the interaction of domestic political institutions and trade competition influences domestic environmental policy responses. ${ }^{1}$ In international trade, price competition is a fact of life in most product categories. Because production and regulatory costs are perceived to influence product pricing, firms, unions, and governments are sensitive about the policies that influence regulatory costs. In the long run, regulatory costs might bear upon the firms' competitiveness even for products which compete on quality attributes instead of cost (Jaffe et al. 1995), because higher regulatory costs can impede productivity growth, thereby leading to higher production costs (Gray and Shadbegian 1995). ${ }^{2}$

How might one expect governments to supply policies in response to such structural pressures to lower regulatory costs? As per the regulatory race hypothesis (Drezner 2001), because governments tend to view themselves in situations of strategic interde- pendence with other countries (Franzese and Hays 2008; Lake and Powell 1999), they are motivated to respond to regulatory policies of their trade competitors. If competitor countries support their firms by reducing regulatory costs, a given country is likely to come under pressure, especially from the exporting sector, to do so as well. Governments might seek to supply policies in two ways. First, they can rewrite environmental regulations. This is an explicit and noticeable policy change which is likely to be opposed by environmental groups. Civil rights group can also get mobilized as evidenced in the literature on environmental racism (Bullard 1999). Thus, making such explicit regulatory changes is difficult. Governments, however, can sneak in less explicit changes which allow businesses to pollute more and externalize their costs. As the recent oil spill in the Gulf of Mexico suggests, instead of rewriting the law, governments can provide regulatory concessions by interpreting the law

\footnotetext{
${ }^{1}$ Data and $\mathrm{R}$ code for replication and an online appendix on improving the model by incorporating government ideologies are available at http://journals.cambridge.org/jop.

${ }^{2}$ Porter and van der Linde (1995) suggest that under some conditions, "appropriately" designed regulations can improve productivity because regulations can incentivize firms to economize on input use. Much of the environmental "command and control" regulations do not correspond to Porter's notion of "appropriately designed" regulations. While scholars debate the empirical validity of the Porter hypothesis, it is our sense that policy actors and interest groups tend to agree that regulations hurt competitiveness, all else equal.
}

The Journal of Politics, Vol. 74, No. 1, January 2012, Pp. 66-82

doi:10.1017/S0022381611001228

(C) Southern Political Science Association, 2012

ISSN 0022-3816 
in ways that favor businesses, by enforcing laws less vigorously, or by constraining regulatory budgets. ${ }^{3}$ The core questions therefore are: who prevails when governments face trade pressures to reduce regulatory costs, and how domestic institutions influence their abilities to supply the policy changes which lower regulatory costs?

Recent work in environmental policy recognizes the relationship between policy interdependence and pollution levels. Konisky (2007) finds that U.S. states respond strategically to other state's policies in the context of federal air, water, and hazardous waste pollution control regulation. In the international context, Cao and Prakash (2010) report that environmental outcomes in a country correspond closely to those of its trade competitor countries. Nevertheless, these studies do not take into account how the interactive effect of structural pressures and domestic institutions, whether at the provincial (U.S. states) or the country level, influences environmental policies. Indeed, much of the trade-environmental literature has paid little attention to how domestic institutions mediate the effects of trade pressures in shaping policy outcomes (Antweiler, Copeland, and Taylor 2001; de Soysa and Neumayer 2005). This is surprising because the broader globalization literature has examined the role of domestic institutions in mediating the pressures of international markets (Garrett 1998; Rudra 2002).

Few political scientists would contest the claim that institutions shape public policy. As rule structures which permit, prescribe, and constrain specific behaviors (North 1990; Ostrom, 1990), domestic institutions constrain governments' response to trade pressures. We focus on veto players, that is, institutional actors whose agreement is necessary for making changes in policy (Tsebelis 1995, 1999). All else equal, the higher the number of veto players and the greater their ideological heterogeneity, the more difficult it becomes for governments to supply policy changes. We suggest that the constraining effect of veto players on policy supply varies as a function of instrument choice (de jure versus de facto changes) and issue (i.e., pollution) visibility. De jure policy changes are explicit in relation to de facto policy changes and therefore impose higher political costs on governments. Pro-environment constituencies should find it easy to identify de jure

\footnotetext{
${ }^{3}$ Federal documents show that the Department of the Interior's Minerals Management Service (MMS) gave BP a "categorical exclusion" on April 6, 2009 to commence drilling with Deepwater Horizon even though it had not produced the impact study required by a law known as the National Environmental Policy Act (http://www.wsws.org/articles/2010/may2010/gulf-m06.shtml, accessed March 27, 2011).
}

policies changes and actively seek allies among veto players to block them. Irrespective of the levels of domestic political constraints, governments will find it difficult to enact de jure changes.

While governments might be able to sneak in de facto policies changes, such changes are a function of domestic veto players. This is because the possibility of stealth changes in the budget for enforcement might also depend on the levels of domestic political constraints. Even in the context of de facto changes, the constraining effect of domestic institutions might also vary across pollutant type. While citizens and environmental groups tend to disfavor pollution, different pollutants are not equally visible across geographies and constituencies. Visible pollutants that affect organized constituencies get policy attention and are more likely to be blocked by veto players. ${ }^{4}$ Because urban areas tend to provide an easier terrain for organizing collective action, policy makers are more attentive to urban pollution concerns.

Air and water pollution differ with respect to issue visibility and have different impacts in urban and rural areas. Compared to water pollution, air pollution is more visible and tends to afflict urban areas. Not surprisingly, air pollution issues mobilize urban constituencies and receive more policy attention. To illustrate, in 2009, the New York Times published a series of articles revealing how federal and state level regulators have not enforced the provisions of the 1972 Clean Water Act. ${ }^{5}$ This contrasts with the zealous enforcement of the Clean Air Act. One article noted that "even as a growing number of coal-burning power plants around the nation have moved to reduce their air emissions, many of them are creating another problem: water pollution." The less attention to water pollution in relation to air pollution can be observed outside the United States as well. Commenting on the oil pipeline accident that polluted China's Yellow River, the Time magazine noted that "while China's air pollution woes are literally more visible and receive more attention, water pollution is generally believed to be the country's more pressing environmental problem."' In Canada, the recent scandal of dumping untreated sewage into water bodies brought light the fact that Canada does

\footnotetext{
${ }^{4} \mathrm{~A}$ similar debate can be found in the public health field. There is a concern among scholars and practitioners that disproportionate policy attention is being paid to diseases such as AIDS in relation to other health problems such as water borne diseases which afflict a much larger number of people.

${ }^{5}$ http://projects.nytimes.com/toxic-waters.

${ }^{6}$ http://www.nytimes.com/2009/10/13/us/13water.html?_r=1.

${ }^{7}$ http://www.time.com/time/world/article/0,8599,1951412,00.html.
} 
not have national standards for sewage treatment. Ecojustice termed a "national disgrace" that coastal cities have been able to dump sewage in open water and remain out of sight and out of mind for many people. ${ }^{8}$ In sum, anecdotal evidence suggests that because air pollution is more visible than water pollution, it tends to get more policy attention. Consequently, policy makers are likely to face higher hurdles if they seek to rollback (in de facto terms) air regulations as opposed to water regulations.

Empirically, we examine a panel of 140 countries for the period 1980-2003. The analyses provide support for our theoretical expectation that countries' de jure regulatory stringency does not respond to pressures from trade competitors at any level of domestic political constraints. In contrast, while governments find ways to lower regulatory costs surreptitiously, their abilities to make de facto regulatory changes depend on domestic political constraints and the issue visibility of the pollutant. In the context of highly visible air pollution, the effect of trade competition on de facto policy changes can be observed only when political constraints are low. For less visible water pollution, the effect of trade competition on de facto policy changes can be observed for a much higher level of political constraints. Thus, constraining effects of veto players on trade competition vary across pollutant types as a positive function of issue visibility.

\section{Policy Interdependence and Domestic Political Institutions}

Scholars identify three broad approaches to analytically examine the processes of policy changes: top-down, bottom-up, and horizontal (Levi-Faur 2005). Top-down explanations view policy changes emanating from exogenous international pressures. These might pertain to structural shifts at the global level such as democratization or the transition to post-Fordist manufacturing. In contrast, bottom-up explanations model policy changes as outcomes of domestic political processes such as national trajectories of industrialization and state building (Thelen 2001), electoral competition (Frye and Mansfield 2004), and the balance of power between business and labor (Rudra 2002). Historically, top-down explanations have tended to find favor with international relations scholars while bottom-up explanations were more popular among comparativists.

${ }^{8} \mathrm{http}: / /$ environment.about.com/od/waterpollution/a/canadasewage. htm.
Both approaches, however, ignore interdependent decision making between states. The third approach views policy outcomes resulting from interdependent decisions that are taken within a group of actors. This horizontal approach has been the focus of the recent studies on policy diffusion covering diverse issue areas such as social welfare policies (Brooks 2007; Weyland 2005), Labor rights (Greenhill, Mosley, and Prakash 2009), liberal market policies (Lee and Strang 2006; Way 2005), environmental policies (Prakash and Potoski 2006; Tews, Busch, and Jörgens 2003), institutional change (Gilardi 2005; Polillo and Guillén 2005), and quality standards (Guler, Guillén, and MacPherson 2002).

Scholars have made important efforts to engage in theoretical discussion regarding the mechanisms of horizontal policy diffusion. Elkins and Simmons (2005) identify two types of diffusion mechanisms: first, adaptation to altered conditions, that is, those for which another's adoption alters the value of the practice (examples here include cultural norms and competition); second, learning, that is, those for which another's adoption provides information. Simmons, Dobbin, and Garrett (2006) emphasize coercion, competition, learning, and emulation among states as channels of policy diffusion. Franzese and Hays (2008) include migration wherein components of some units move directly into others and generate direct and mechanical interdependence. Along with examining mechanisms of diffusion, scholars have recognized that domestic variables constrain such diffusion processes. For example, Dolowitz and Marsh (2000) note that structural and institutional factors can constrain policy diffusion. They, however, do not provide a theoretical framework to incorporate these domestic institutional factors into the theoretical model of policy diffusion.

There is some empirical work exploring the mediating effects of domestic variables. Swank (2006) tests a variety of conditional effects of domestic variables (e.g., government ideology, median voter, and national and sector coordination) on the diffusion of liberal tax rates. Jo (2009) examines the conditional effect of domestic regulatory quality on the diffusion of international accounting standard. Brooks and Kurtz (2009) demonstrate that the experience of advanced import substituting industrialization conditions the patterns of capital account liberalization in Latin America. Kerner and Kucik (2010) find that variation in the adoption and enforcement in insider trading laws can be best explained by the interaction of international competitive pressures and electoral laws.

This discussion suggests that the choice of domestic variables is contingent on both the policy area 
and the specific diffusion mechanism. In our context, to measure policy interdependence induced by trade competition, we use the concept of structural equivalence. This concept is motivated by sociological studies on position similarity in networks such as corporate linkages, international trade, and transnational investments (Burt 1976; Hanneman and Riddle 2005). The key finding of these studies is that similar positions in the network often induce competition among actors occupying these positions. The same rationale applied in the context of international trade suggests that two countries might be strategically interdependent if they occupy similar positions in the global trade network: they are connected to the world market in a similar fashion, that is, they export the same products or their close substitutes to the same foreign markets. Position similarity is likely to induce competition between countries, because from the buyer's perspective, the products offered by their firms are substitutable (Borgatti and Everett 1992). Our theoretical story centers on the effects of trade competition on environmental regulations. As we explain below, we focus on veto players as the domestic institution because their effects on policy change can be observed across a wide range of political settings.

\section{Policy Changes and Veto Players}

Comparative political economists have studied how domestic institutions such as types of authoritarian states (Geddes 1994), electoral rules (Frye and Mansfield 2004), corporatist institutions (Thelen 2001), and partisanship (Garrett 1998), influence policymaking. Environmental policy scholars have also identified the important role of domestic political institutions in shaping environmental outcomes (Bernauer and Koubi 2009; Li and Reuveny 2006; Scruggs 1999). How political institutions influence policy interdependence among states, however, has received scant scholarly scrutiny.

To understand how domestic institutions mediate trade pressures, we examine the role of veto players (political constraints) which exist in all types of regimes, even in nondemocracies (Ganghof 2003). Given that policy processes seldom involve a unitary decision maker (Mansfield, Milner, and Pevehouse 2008), veto players-individual or collective actor (such as a political party) whose consent is needed to change the status quo (Tsebelis 1995)—can use their veto power to block policy changes. An increase in the number of veto players and/or their preference heterogeneity disperses decision-making authority in a state and limits the extent to which the same level of demand (trade competitive pressures in our article) can alter the status quo (Tsebelis 1995, 1999).

While the veto player framework has been applied extensively to study various topics, our article makes a novel theoretical contribution. Unlike much of the veto player literature which focuses on impediments to policy change, we nuance the policy change dimension by examining the differential impact of veto players on de jure change (rewriting regulations) and de facto change (e.g., via lax enforcement, business friendly interpretations of existing laws, budgetary cuts, etc.) in the context of pollution issues with different level of visibility. Our environmental politics model examines how governments respond to interest groups, some of which seek lowering of regulations while others argue against such changes. We assume that the government wants to stay in power. Therefore, it needs to respond to societal pressures. Moreover, the government cares about the competitiveness of exporting industries and therefore has incentives to improve/sustain competitiveness of their firms: governments, both democratic and nondemocratic, often lose office if they cannot deliver economic welfare to the society. While we recognize that government can serve as more than simple aggregator of societal interests, to be more theoretically focused, we leave out factors such as government ideology. ${ }^{9}$

Regarding interest groups, the pro-environment interest groups that favor stringent environmental regulations include urban residents and environmental NGOs. We focus on urban residents and NGOs because in terms of policy preferences, rural-urban divide might exist. For example, because rural residents in industrialized countries rely more heavily on fossil fuels (mainly for transportation over longer distance) in relation to urban dwellers, they are likely to prefer lower gasoline taxes (Broz and Maliniak 2010). Moreover, the most active pro-environment citizen groups and NGOs tend to reside in urban

\footnotetext{
${ }^{9} \mathrm{We}$ assume that government seek to remain in power, a simplifying assumption that lends explanatory power to the model. We recognize that government ideology might affect domestic politics: a right/pro-business government might favour lowering regulatory stringency, thereby further weakening the constraining effect of veto players. Therefore, the effect of trade competition on environmental regulations might be strongest under a right government with lowest levels of veto players; weakest under left/pro-environment government with lowest levels of domestic constraints. We tested such a model and reported the empirical findings in an online appendix for this article. While we find no evidence regarding the effect of government ideology (left-right dimension), we recognize that the nonfinding might reflect data coverage and quality: we only have 27 OECD countries with cross-nationally comparable and detailed data measuring government ideology.
} 
areas. Therefore, we consider urban residents and environmental NGOs the most important proenvironment constituencies in our theoretical model. Finally, the other key interest group in the model is the business sectors (including both capital and labor). Because they benefit from improved trade competitiveness, these actors have incentives to lobby for lowering regulatory stringency. In the context of trade competition, this group mainly include exporting sectors whose production costs are affected by environment regulations. ${ }^{10}$ By and large, even industries that predominantly serve the domestic market tend to prefer lower environmental regulatory costs. ${ }^{11}$ Hence, there tends to be convergence of preferences on this subject among exporting and domestic sectors.

The government, pro-environment constituencies, and exporting sectors interact with one another in domestic political institutional settings. The characteristics of political institutions influence policy outcomes. We focus on veto players because they are an analytically elegant way to model institutional constraints for both the de jure and the de facto policy change. In general, established literature on veto players has shown that the possibility and the extent of policy change is a negative function of their number and ideological heterogeneity (Tsebelis 1995, 1999). We nuance this argument by suggesting that the constraining effect of domestic veto players is not constant across pollution types because of their different levels of issue visibility. Veto points provide institutional opportunities to block change. The extent to which different constituencies will be motivated to exploit these opportunities will depend on the visibility of the pollutant. Thus, an analysis of the constraining effect of veto players must take into account the agency of the interest group that seeks to block the change.

\footnotetext{
${ }^{10}$ Facing trade competition, exporting sector might have other responses. Firms might even have incentive to lobby for more stringent regulations if they have first-mover advantages in green technologies. For countries competing in labor-intensive product markets, upgrading is another option; countries competing in high-end production can further investments in research and development. However, these alternatives are generally more costly and difficult. For developing countries, moving up the production chain is difficult, if not impossible (Doner, Ritchie, and Slater 2005). For developed countries, some firms compete on quality rather than on price. However, few firms competing in the global market can afford to ignore the price aspect of the competition. Even German firms, famous for high-quality production, have taken steps to take advantage of geographical proximity to low-cost labor in Central and Eastern Europe (Bluhm 2000).

${ }^{11}$ In most countries, "green industries" which benefit from tougher environmental regulations constitute a small portion of the economy.
}

\section{Policy Changes and Issue Visibility}

De jure policy changes are explicit and therefore become the target of interest group mobilization. Even under strong trade competition pressure, government are likely to face difficulties in initiating downward regulatory changes. Regulated firms are often portrayed as strategic actors in the recent environment regulation literature. For example, in some cases, regulated firms, seeking to offset pollution costs, might substitute pollution between different media (Alberini 2001; Sigman 1996). ${ }^{12}$ In our model, firms are expected to be strategic in the sense that they identify the opportunities for targeting lobby activities. For them, politically sensitive de jure changes tend to impose high costs and provide low returns because the political space available for government to manoeuvre is limited. Therefore, we expect that that regardless of the level of domestic political constraints and the pollution type, trade competition is unlikely to have impact on the de jure aspect of environmental regulations.

The de facto policy changes are less explicit than de jure policy changes. ${ }^{13}$ The political costs of supplying such changes might be lower for governments, especially on pollution issues where organized constituencies are not mobilized. As a function of business pressure and/or government's own concern over national industries losing competitiveness in the global market, governments might choose to retain the regulations on paper but weaken them in practice. One way to weaken regulations is to cut enforcement budgets. For instance, the United States, the first-mover and the leader in the sphere of environmental regulation, has underfunded the Environmental Protection Agency, especially the enforcement wing, rendering the organization unable to properly

\footnotetext{
${ }^{12}$ The argument of strategic choice was first made in the context of the pollution haven hypothesis: in response to domestic legislations, firms in developed countries shifted the production of toxic materials to overseas locations with allegedly lax environmental laws. In the domestic context, there is some evidence of strategic choices by firms. Gamper-Rabindran (2006) reports that in response to the reporting requirements under the U.S. Environmental Protection Agency's Toxics Release Inventory Program, industrial plants do not reduce emissions in less politically active communities; firms in some industries reduce pollution, but at the same time increase their transfers to the offsite recyclers (which are not counted as the facility's emission).

${ }^{13}$ Acemoglu and Johnson (2005) have examined the relationship between de jure and de facto institutions. There is some discussion on the de facto versus de jure dimension in other policy areas as well. For example, Massey and Denton (2003) suggest that local governments find it difficult to allow de jure racial discrimination as opposed to de facto discrimination in the context of U.S. schooling systems.
} 
enforce its own regulations (Fiorino 2006). ${ }^{14}$ Another way is to reduce the budget allocated to rule writers. This way even for laws that have been passed by the legislature, the enforcement agency may not have the budget to translate the statute into tangible rules. ${ }^{15}$ Generally, when political constraints are low, it is easier for the government to change the budget for the implementation of the existing regulations. Therefore, we are more likely to observe the effect of trade competition on de facto policy changes in settings characterized by low levels of political constraints.

Moreover, even in the context of de facto changes, the supply of policy response is likely to vary across pollutant type. This is because pollutants have different levels of issue visibility and therefore lead to different types of counter mobilization by pro-environmental constituencies. Changes in policy implementation in certain policy areas are more visible to the well organized pro-environment constituencies that are often based in urban areas: for example, compared to the water pollution issue, air pollution often has higher visibility and tends to afflict all urban areas. Indeed, the largest share of $\mathrm{SO}_{2}$ emissions stems from stationary sources such as electricity generation, iron and steel industries, and transportation. This tends to be visible and therefore politically sensitive. Furthermore, traffic and industrial activity tend to make air pollution a salient urban policy issue where the vocal and organized environmental groups tend to reside. In contrast, not all cities are adjacent to big water bodies such as major rivers, lakes, and sea coasts. This tends to make water pollution, on average, less visible than air pollution. In addition, water pollution created by the city in the form of sewage or industrial discharges tend to go downstream. They become out of sight and therefore out of mind. On other hand, air pollution such as smog, acid rain, and dry deposition caused by $\mathrm{SO}_{2}$ emissions often stay and are visible to urban residents. Finally, in some cases, water could be polluted but looks clear to naked eyes, for example, nitrogen fertilizer pollution in water. Thus, the severity of the pollution may remain unrecognized in the case of water pollution, all else equal.

\footnotetext{
${ }^{14}$ On the general subject of enforcement shortfalls, see the EPA's Inspector General's report, http://www.epa.gov/oig/reports/2001/ enforce.pdf. In international context, a 2006 OECD report documents challenges in enforcement in China (http://www.oecd. org/dataoecd/33/5/37867511.pdf).

${ }^{15}$ This strategy of reducing the budget to rule writers is unlikely to be pursued by the government in countries that have an administrative procedures act specifying when rules have to be written and when public comment has to be open. Lack of rulewriting activity would be noticeable in these countries. For these countries, reducing the funds for enforcement is more likely the dominant strategy.
}

Therefore, we expect that changes in the de facto environmental policies in the context of air pollution are more likely to lead to the counter mobilization of organized, urban pro-environment constituencies. They are more likely to find allies among the veto players to block the de facto policy changes initiated by the government and lobbied by export sectors. In a way, they amplify the mediating effects of political constraints to resist de facto policy changes. Our theoretical expectation, therefore, is that in the context of visible policy issues, the effect of trade competition on de facto changes is likely to be observed only when the level of political constraints is low.

To recap, we expect that for de jure policy changes, trade competition is unlikely to have an effect on environmental policy regardless of the level of domestic constraints because of the publicity and potential political opposition associated with de jure changes. However, governments can and often do sneak in de facto policy changes. Figure 1 summarizes the key theoretical expectations regarding the effect of trade competition on de facto policy changes: we expect it to be a function of both the level of domestic political constraints and the level of issue visibility associated with pollutant types. The constraining role of domestic political constraints is a positive function of issue visibility: issue visibility amplifies the constraining effect of domestic veto players, because high-issue visibility induces stronger countermobilization from pro-environment

\section{Figure 1 Effect of Trade Competition Conditioning on Domestic Constraints and Issue Visibility}

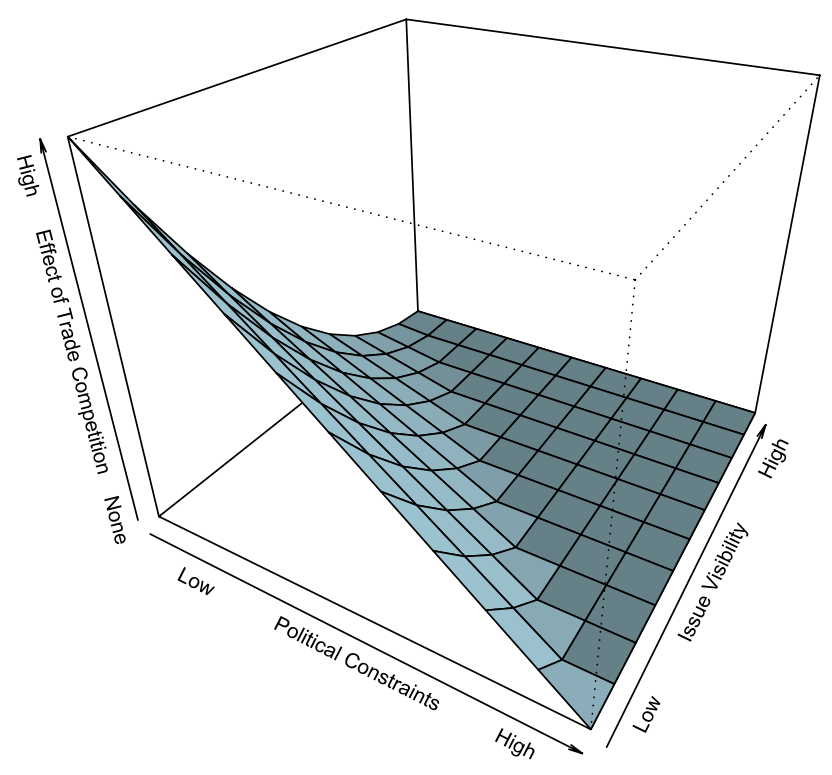


constituencies which often finds allies among veto players to block de facto policy changes.

\section{Constructing Variables}

Ideally, to test the regulatory race hypothesis one would examine how regulatory stringency in a given country responds to the regulatory changes in competitor countries. This strategy poses empirical difficulties because one cannot find systematic longitudinal data on de jure regulatory stringency for a sufficient cross-section of countries. Scholars, therefore, employ international environmental treaty commitment as a proxy for de jure stringency of domestic environmental regulations (Neumayer 2002). Theoretically, treaty commitment should strongly correlate with regulatory stringency because environmental treaties often require signatories to enact certain regulations (Ehrlich 2009).

Nevertheless, we sought to empirically verify the correlation between international treaty commitment and de jure domestic regulatory stringency for the panel of countries for which data are available. For the former, we use the Environmental Treaties and Resource Indicators (ENTRI) database which record the environmental treaties that a country signs or becomes a party to for the period $1902-2000 .{ }^{16} \mathrm{We}$ use the current number of treaties to which a country is a party as a measure for the country's international environmental commitment. For domestic regulatory stringency, we use the ENVIPOLCON database, ${ }^{17}$ which record domestic environmental policies and regulations for 24 countries and for 1970, 1980, 1990, and 2000. Based on the ENVIPOLCON data, we count the number of domestic environmental policies in place; these include 29 categories/items and each of the items is coded as binary, with 1 indicating that such a policy is in place in the country-year and 0 otherwise. ${ }^{18}$ While limited in its temporal and geographical coverage, this provides a sense of de jure aspect of domestic environmental regulations. Using the overlapping country-years between the two data sets, based on 96 observations, we calculated the

\footnotetext{
${ }^{16}$ Data are from the Center for International Earth Science Information Network (CIESIN) at Columbia University: http:// sedac.ciesin.columbia.edu/entri/.

${ }^{17}$ ENVIPOLCON: Environmental Governance in Europe. http:// www.uni-konstanz.de/FuF/Verwiss/knill/projekte/envipolcon/ project-homepage.php.

${ }^{18}$ The 29 policy items include, for example, whether there is policy/regulation in place concerning exhaust emissions cars; policy/regulation for airborne emissions; and regulation for efficient use of water industry.
}

correlation between the ENTRI data on countries' international environmental treaty commitment and the ENVIPOLCON data on domestic de jure environmental policies. The correlation is 0.88 , which gives us confidence that a country's international environmental treaty commitment is a reasonable proxy for the de jure aspect of environmental regulations.

Even with stringent laws on the books, governments might cut enforcement budgets, reduce penalties for enforcement violations, and adopt administrative policies, all of which undermine enforcement effectiveness. Governments can diminish regulatory stringency without rewriting the law. We, therefore, assess levels of de facto regulatory stringency by looking at environmental policy outcomes, that is, pollution per unit of GDP (i.e., pollution intensity). When existing laws are stringent and enforced, pollution intensity is low, all else equal. This often translates into higher regulatory costs for domestic firms. If laws are not stringent and/or not enforced, pollution intensity is high, all else equal. This would translate into lower regulatory costs for domestic firms. Because de jure regulatory stringency is less likely to vary over time, it is likely to be captured by the lagged dependent variable and fixed country effects in the empirical analysis. In contrast, de facto stringency is likely to vary overtime. Thus, the pollution intensity measures are likely to reflect enforcement stringency dimension of the regulatory system.

To measure de facto environmental regulations, we employ two indicators, one for air pollution intensity ( $\mathrm{SO}_{2}$ : sulphur dioxide) and one for water pollution intensity (BOD: biochemical oxygen demand). For $\mathrm{SO}_{2}$, the variable is reported in (logged) grams of $\mathrm{SO}_{2}$ per unit of gross domestic product (measured in constant 2000 dollars based on purchasing power parity). For water pollution, the variable is reported in (logged) grams of biochemical oxygen demand (BOD) per unit of gross domestic product (in constant 2000 dollars based on purchasing power parity). $\mathrm{SO}_{2}$ and BOD serve as reasonable proxies for the de facto stringency of environmental regulations. They are outcomes of production processes and tend to be regulated pollutants. ${ }^{19}$ Air and water quality are important indicators of how economic actors respect or neglect the environment. Furthermore, abatement technologies are available for both $\mathrm{SO}_{2}$ and BOD. Because these technologies have nontrivial costs, their adoption and the consequent reductions in pollution levels are likely

\footnotetext{
${ }^{19}$ The $\mathrm{SO}_{2}$ data are from Stern 2005. BOD data are from the World Development Indicators. See World Bank (2008).We do not consider carbon dioxide $\left(\mathrm{CO}_{2}\right)$ as a response variable primarily because it tends to be nonregulated in most countries and therefore not a good proxy of de facto regulatory stringency.
} 
to be influenced by competitiveness concerns. Additionally, since we are using a panel design to test the regulatory race argument, we need to focus on response variables for which data are available for a relatively long time series. ${ }^{20}$ Indeed, longitudinal data for $\mathrm{SO}_{2}$ and $\mathrm{BOD}$ emissions are available for both developed and developing countries. ${ }^{21}$ Finally, by looking at two pollutants with different levels of issue visibility (air pollution $>$ water pollution), we can test our theoretical expectations on how issue visibility affects the mediating effects of domestic political constraints.

\section{Independent Variables}

To capture competition among countries that serve the same export markets with similar products, we calculate pair-wise structural equivalence based on sector-level bilateral trade data. We employ the United Nations' Standard International Trade Classification (SITC) to identify 10 broad trade sectors in international commerce: (1) food and live animals directly for food; (2) beverages and tobacco; (3) crude materials, inedible, except fuels; (4) mineral fuels, lubricants and related materials; (5) animal and vegetable oils, fats and waxes; (6) chemical and related products; (7) manufactured goods, classified chiefly by material; (8) machinery and transport equipment; (9) miscellaneous manufactured articles; (10) commodities and transactions not classified elsewhere.

Structural equivalence is calculated by taking the correlation between two countries' exports at both bilateral and sector levels. Therefore, a given country's "export profile" is composed of $k \times(n-1)$ elements in which $n$ is the total number of countries, and $k$ is the number of trade sectors. Data are from the United Nations' Comtrade database. This data set covers international commerce at the dyadic level since 1962 and for different commodities detailed to the level of five-digits SITC. Aggregating to the one-

\footnotetext{
${ }^{20}$ This is the key reason why we do not employ response variables such as NOx emissions as in Li and Reuveny (2006) and carbon footprint as in York, Rosa, and Dietz (2003).

${ }^{21}$ Pollution intensity (pollution per GDP) is a proxy for de facto regulations. Given that it is also function of other factors such as domestic regulation and similarities in economic structure, our model controls for important economic and other variables which might drive pollution intensity.
}

digit level yields the 10 distinct sectors that we just described. ${ }^{22}$ A correlation matrix of each country's exports across the 10 trade sectors and to all other countries is then generated to capture this structural similarity.

The value of correlation capturing the structural equivalence between countries $i$ and $j$ in a given year $t$ (struc.equivi,j,t) is bounded between -1 and 1 , with 1 representing complete structurally equivalence of two countries. This means these countries have the exact profiles of bilateral exports to other countries across 10 sectors of trade. The value of -1 captures the situation where two countries share the most dissimilar export profiles. While countries naturally compete in different export markets, only those exporting the same products to the same export market are likely to consider one another as competitors. We assume, therefore, that for any country $i$, export-induced competitive pressures only come from countries that have a positive score of structural equivalence with $i$, that is, only when struc.equiv $i_{i, j, t}>0$. For country $i$, the influence from a competing exporter $j$ in year $t$ in setting its environmental standards can be summarized as $\frac{\text { struc.equiv }_{i, j, t}}{\sum_{j \neq i}^{n} \text { struc.equiv }_{i, j, t}}$. Note that we have standardized struc.equivi,j,t by $\sum_{j \neq i}^{n}$ struc.equiv $_{i, j, t}$, which is the sum of the total competitive pressure faced by country $i$ from all its competitors. ${ }^{23}$ If country i's decision to set its environmental standards is influenced by the decisions of its key trade competitor countries, we expect that its environmental standard indicators are associated with the weighted average levels of these indicators in competitor countries. We therefore use this standardized structural equivalence score to weight the policy outputs (using international treaty commitment as a proxy) and policy outcomes (measured by $\mathrm{SO}_{2}$ and $\mathrm{BOD}$ pollution intensities), respectively, in country is competitor countries: $\sum_{j \neq i}^{n}\left(\frac{\text { struc.equiv }_{i, j, t}}{\sum_{j \neq i}^{n} \text { struc.equiv }_{i, j, t}}\right) \times$ de.jure.stringency $y_{j, t}$

\footnotetext{
${ }^{22}$ While we appreciate the advantages of disaggregating bilateral export data beyond sector level, data quality diminishes when one moves to higher-digits levels (e.g., more missing values). For more discussion on higher-digits SITC levels and applications at two-digits SITC, see Mahutga (2006) and Cao and Prakash (2011).

${ }^{23} \sum_{j \neq i}^{n}$ struc.equiv $_{i, j, t}=$ struc.equiv $_{i, 1, t}+\ldots+$ struc.equiv $_{i, j, t}+\ldots+$ struc.equiv $_{i, n, t}, j \neq i$. We posit that $j$ 's influence on $i$ is a relative term, defined by the relative importance of $j$ 's competitive pressure on $i$ (struc.equvi $i_{i, j, t}$ ) to the total competitive pressure faced by $i$ from its competitors $\left(\sum_{j \neq i}^{n}\right.$ struc.equiv $\left._{i, j, t}\right)$.
} 
is therefore the weighted average of country is competitor countries' de jure regulatory stringency (de. jure.stringency $y_{j, t}$ is the logged current number of international environmental treaties to which a country $j$ is a party); $\sum_{j \neq i}^{n}\left(\frac{\text { struc.equiv }_{i, j, t}}{\sum_{j \neq i}^{n} \text { struc.equiv }_{i, j, t}}\right) \times$ de.facto.stringency $y_{j, t}$ is the weighted average of country i's competitor countries' de facto policies; this is calculated separately for air $\left(\mathrm{SO}_{2}\right)$ and water pollution (BOD) intensities.

Note that the weighted average of country i's competitor countries' environment regulatory indicator can be considered as a typical spatial lag term in a spatial lag model. The difference is that the weight is defined by structural equivalence in trade instead of geographical proximity. We therefore use a simpler notation $w_{i, j, t}^{\text {Struc.Equiv. }}$ for structural equivalence in trade. Further, the notation $\mathbf{y}_{t}$ can be thought of, for example, for de facto policy outcomes, as a vector containing pollution intensity levels for all countries in year $t$. The pressure from competitor countries regarding environmental regulations, as reflected in the weighted average of country is competitor countries' pollution intensities, can therefore be expressed as a spatial lag term: $\mathbf{w}_{i, t}^{\text {Struc.Equiv. }} \mathbf{y}_{t}{ }^{24}$

The data on veto players are taken from Henisz (2002) that measures the presence of branches of government outside the executive's control, the extent to which these branches are controlled by the same political party as the executive, and the homogeneity of preferences within these branches. The resulting measure is a continuous variable ranging from 0 to 1 . When the value of the variable veto player equals 0 , there are no veto players in the state. Higher values indicate the presence of effective branches of government to balance the chief executive. In cases where effective branches exist, these variables take on larger values as party control across some or all of these branches diverge from the executive's party. The

\footnotetext{
${ }^{24} \mathrm{We}$ can use a simple notation $\mathbf{W}_{t}^{\text {Struc.Equiv. }}$ to represent the whole weight matrix to capture the effects of trade competition among countries for year $t$ : $\mathbf{W}_{t}^{\text {Struc.Equiv. }}$ is a $\mathrm{N}$ by $\mathrm{N}$ weight matrix ( $\mathrm{N}$ equals the number of countries); $\mathbf{w}_{i, t}^{\text {Struc.Equv. }}$ is therefore the $i$ th row of the matrix and $w_{i, j, t}^{\text {Struc.Equiv. }}$ (i.e., $\left.\frac{\text { struc.equiv }_{i, j, t}}{\sum_{j \neq i}^{n} \text { struc.equiv }_{i, j, t}}\right)$ is the $j$ th element in this row which reflects the influence of country $j$ on $i$ in year $t$. For de jure policy stringency/policy outputs, $\mathbf{y}_{t}$ is a vector containing treaty commitment for all countries in year. For de facto policy outcomes, $\mathbf{y}_{t}$ is a vector containing pollution intensity levels for all countries in year $t$ : the $j$ th element of $\mathbf{y}_{t}$ is therefore de.facto.stringenc $y_{j, t}$. We follow stand-

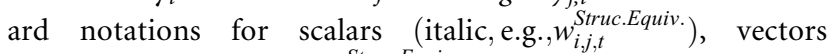
(bold lower - case, e.g., $\mathbf{w}_{i, t}^{\text {Struc.Equiv. }}$ ), and matrices (bold uppercase, e.g., $\mathbf{W}_{t}^{\text {Struc.Equiv. }}$ ).
}

Henisz veto player (or political constraints) measure echoes those produced in similar work by Tsebelis (1995, 1999), and it is theoretically derived from a single-dimensional, spatial model of policy choice that allows the status quo and the preferences of veto players to vary across the entire space. More specifically, Henisz (2002) finds that (1) each additional veto point (a branch of government that is both constitutionally effective and controlled by a party different from other branches) provides a positive but diminishing effect on the total level of constraints on policy change; and (2) homogeneity (heterogeneity) of party preferences within an opposition (aligned) branch of government is positively correlated with constraints on policy change. Another advantage of the Henisz' data is its coverage. Unlike Tsebelis' data that include some OECD countries, Henisz' data cover almost all countries from 1960 to 2004. Figure 2 shows the "threemodal" density distribution of the veto player variable for the country-years covered by this study.

\section{Control Variables}

While trade competition, veto players, and their interactions are the key variables, our model controls for several other factors which can bear upon de jure and de facto policy changes. ${ }^{25}$ We controls for trade salience (sum of imports and exports as a percentage of GDP): trade salience is conceptually important as it reflects the actual and perceived economic conditions and levels of insecurities associated with the vagaries of the global market which might affect the chances to unleash changes in domestic environmental policies. Inward foreign direct investment is another important factor that might impact domestic pollution levels. We measure a host country's overall dependence on inward FDI (FDI Stock) based on the argument that irrespective of the FDI source, higher levels of inward FDI influence host countries' pollution levels. FDI Stock is calculated as a host country's total inward FDI stock as a percentage of GDP. Data are from UNCTAD (2008).

We include both GDP per capita (in purchasing power parity) and its squared term in the model to

\footnotetext{
${ }^{25} \mathrm{We}$ consider the number and the ideological dispersion of veto players only in this article. But other characteristics of domestic politics might also influence the stringency of regulations. There is some evidence that green governments and left governments put more emphasis on the environmental protection (Daugsberg and Svendsen 2001; Neumayer 2003; Ward and Cao, Forthcoming). Unfortunately, the data on greenness of governments exist for the OECD countries only (Klingemann et al. 2006). For left-right dimension of the government, please see the online appendix for our test on a model with government ideologies.
} 


\section{Figure 2 Density Distribution of Veto Player Data, 1980-2004}

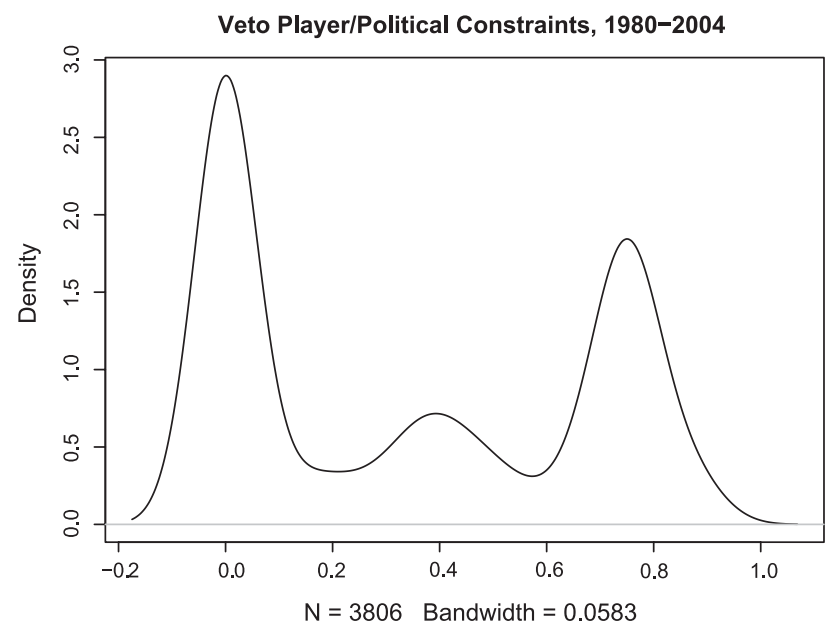

capture the curvilinear relationship between wealth and environmental protection: the Environmental Kuznets Curve argument posits that there is a U-shape relationship between income/economic development and environmental protection. We also control for GDP growth rate. While higher growth rates often require more intensive use of resources and lead to higher levels of pollution, they may also encourage technological advancement and human capital accumulation that might eventually improve environmental quality. Our model includes the share of industrial production in GDP because the industrial production is often associated with higher levels of pollution intensity in relation to service and agricultural sectors, and therefore demand for less stringent environmental regulations. We also include two demographic variables, population density (population divided by land area) and urban population (as a share of total population) to control for demographic influences on pollution levels. Countries with high population density might prioritize development at the expense of environmental protection. Large urban population might also increase environmental burden of the country; but urban population is also likely to be associated with environmental activism and protection. ${ }^{26}$ Table 1 presents the summary statistics for the variables included in our empirical analysis.

\footnotetext{
${ }^{26}$ Data on GDP per capita, GDP growth rate, industrial production, oil exports, population density, and urban population are from the World Development Indicators (World Bank 2008).
}

\section{A Spatial Model with the Mediating Effects of Veto Players}

Recent policy diffusion literature employs spatial lag models to capture the effects of policy interdependence. ${ }^{27}$ Such a model can be written as follows:

$$
\begin{aligned}
y_{\mathrm{i}, t}= & \beta_{0}+\varphi y_{\mathrm{i}, \mathrm{t}-1}+\mathbf{x}_{\mathrm{i}, t} \beta+\rho_{\text {s.e. }} \mathbf{w}_{\mathrm{i}, \mathrm{t}-1}^{\text {Struc.Equiv. }} \mathbf{y}_{\mathrm{t}-1} \\
& +C_{i}+T_{t}+\varepsilon_{\mathrm{i}, \mathrm{t}}
\end{aligned}
$$

For our article, $y_{\mathrm{i}, \mathrm{t}}$ is the dependent variable: de jure regulatory stringency measured by the logged current number of international environmental treaties to which a country $i$ is a party as well as de facto regulatory stringency measured by air $\left(\mathrm{SO}_{2}\right)$ and water (BOD) pollution intensity respectively. $\beta_{0}$ is the population intercept, $\varphi y_{\mathrm{i}, \mathrm{t}-1}$ captures the effects of lagged dependent variable $y_{\mathrm{i}, \mathrm{t}-1}$, and $\mathbf{x}_{\mathrm{i}, \mathrm{t}} \beta$ the effects of countryspecific characteristics.

$\rho_{\text {s.e. }} \mathbf{w}_{\mathrm{i}, \mathrm{t}-1}^{\text {Struc.Equiv. }} \mathbf{y}_{\mathrm{t}-1}$ represents the temporarily lagged spatial lag term of the network diffusion effect induced by structural equivalence in trade, that is, the weighted average of trade competitor countries' treaty commitment and pollution intensity levels. Here, $\rho_{\text {s.e. }}$ represents the spatial coefficient that we estimate to capture the effects of trade competition on environmental outcomes. Notice that in order to mitigate the simultaneity bias in the estimation of spatial lag models, the spatial lag $\left(\rho_{\text {s.e. }} \mathbf{w}_{\mathrm{i}, \mathrm{t}-1}^{\text {Struc.Equiv }} \mathbf{y}_{\mathrm{t}-1}\right)$ are lagged by one year. The assumption here is that outcomes in country $i$ get influenced by outcomes in other connected countries after a time lag. Lagging the spatial lag has become a common practice in some of the recent studies of policy diffusion and neighborhood effects on policy choices (Elkins, Guzman, and Simmons 2006; Lee and Strang 2006), mainly because it provides a simpler way to estimate the strength of interdependence (by simple OLS regression) in relation to a spatial maximum likelihood approach (spatial ML) and spatial two-stage-least-squares instrumental variable approach (2SLS). ${ }^{28}$ However, this strategy of lagging the spatial lag terms is based on a strong

\footnotetext{
${ }^{27}$ For articles in environmental studies with spatial models, see, for example, Murdoch, Sandler, and Sargent (1997), Fredriksson, List, and Millimet (2004), and Ward and Cao (Forthcoming).

${ }^{28}$ Recent efforts by Franzese and Hays have made spatial maximum likelihood approach (spatial ML) easier to implement (e.g., Franzese and Hays 2006).
} 
Table 1 Summary Statistics Based on all Available Observations between 1980 and 2003

\begin{tabular}{lrrrrr}
\hline & N & Mean & SD & Min & Max \\
\hline Treaty (before taking logarithm) & 3822 & 42.93 & 32.83 & 0.00 & 185.00 \\
BOD per GDP (grams, before taking logarithm) & 2081 & 0.35 & 0.27 & 0.00 & 2.32 \\
SO2 per GDP (grams, before taking logarithm) & 3004 & 2.99 & 7.29 & 0.00 & 106.99 \\
Veto Player & 3490 & 0.34 & 0.34 & 0.00 & 0.89 \\
Structural equivalence of trade: treaty (logged) & 3627 & 3.40 & 0.37 & 1.66 & 4.50 \\
Structural equivalence of trade: BOD per GDP (logged) & 4025 & -5.33 & 1.33 & -9.02 & -2.12 \\
Structural equivalence of trade: SO2 per GDP (logged) & 4025 & -2.70 & 1.80 & -9.21 & -0.20 \\
Trade salience (\% of GDP) & 3829 & 68.43 & 39.99 & 6.32 & 290.90 \\
FDI stock (\% of GDP) & 3863 & 16.55 & 19.80 & 0.00 & 185.50 \\
GDP per capita & 3795 & 7678.63 & 8110.41 & 459.30 & 53339.62 \\
Industry (\% of GDP) & 3675 & 29.86 & 12.18 & 1.88 & 89.15 \\
GDP growth ((\% of GDP)) & 4068 & 2.97 & 6.55 & -51.03 & 106.28 \\
Population density (people per sq. km) & 4624 & 239.83 & 1125.75 & 0.14 & 16564.10 \\
Urban population (\% of total) & 4896 & 51.79 & 24.74 & 4.30 & 100.00 \\
\hline
\end{tabular}

assumption, that is, the absence of instantaneous effect. ${ }^{29}$ Moreover, in the analysis of spatial interdependence, it is of great importance that common external shocks (for example, oil crisis) are controlled and distinguished from interdependence. Equation (1) therefore includes year dummy variables $\left(T_{t}\right)$ to control for potential common shocks. Finally, we allow for cross-sectional heterogeneity by including country fixed effects $\left(C_{i}\right) .^{30}$

To test the mediating effects of domestic veto players, we use an interaction term of the spatial lag for trade competition $\left(\mathbf{w}_{\mathrm{i}, \mathrm{t}-1}^{\text {Struc. Equiv. }} \mathbf{y}_{\mathrm{t}-1}\right)$ and domestic veto players $\left(\right.$ Veto $\left._{i, t-1}\right)$. We add the interaction term $\left(\right.$ Veto $\left._{i, t-1} \times \mathbf{w}_{\mathrm{i}, \mathrm{t}-1}^{\text {Struc.Equiv. }} \mathbf{y}_{\mathrm{t}-1}\right)$ into equation (1), which results in:

\footnotetext{
${ }^{29}$ Meanwhile, lagging the spatial lags can only be a sound solution to the simultaneity bias if the errors, $\varepsilon_{i, t}$ in equation (1), are serially independent. If $\varepsilon_{\mathrm{i}, \mathrm{t}}$ is not serially independent, for example, when $\varepsilon_{\mathrm{i}, \mathrm{t}}$ follows an $\mathrm{AR}(1)$ process: $\varepsilon_{\mathrm{i}, \mathrm{t}}=\gamma \varepsilon_{\mathrm{i}, \mathrm{t}-1}+$ $\eta_{i, t}$, equation (1) becomes $y_{\mathrm{i}, \mathrm{t}}=\beta_{0}+\varphi y_{\mathrm{i}, \mathrm{t}-1}+\mathbf{x}_{\mathrm{i}, \mathrm{t}} \beta+\rho$ $\mathbf{w}_{\mathrm{i}, \mathrm{t}-1}{ }^{\star} \mathbf{y}_{\mathrm{t}-1}+C_{i}+T_{t}+\gamma \varepsilon_{i, \mathrm{t}-1}+\eta_{i, t}$. Notice that $\varepsilon_{\mathrm{i}, \mathrm{t}-1}$ is the error term for the right-hand-side variable $y_{\mathrm{i}, \mathrm{t}-1}$. The fact that they are both at the right-hand-side of the equation causes simultaneity bias. Using a Lagrange Multiplier test, we test the existence of serial correlation in error terms after estimating equation (1) by OLS. We find no serial correlation.

${ }^{30} \mathrm{We}$ recognize a clear simultaneity problem here as the lagged dependent variable is correlated with the error term by virtue of its correlation with the time-invariant component of the error term. When country fixed effects are included, the lagged dependent variable will still be correlated with the error term, and this leads to the Nickell bias. However, recent literature suggests that the Nickell bias is really negligible, and all remedies (such as Anderson-Hsiao or Arellano-Bond) are worse than the original Nickell bias (Adolph, Butler, and Wilson 2005; Kiviet 1995). Fortunately, as T (number of years) gets larger, this bias becomes less of a problem. We have a time series of more than 20 years, and we believe this is still a relatively large $\mathrm{T}$.
}

$$
\begin{aligned}
y_{\mathrm{i}, \mathrm{t}}= & \beta_{0}+\varphi y_{\mathrm{i}, \mathrm{t}-1}+\mathbf{x}_{\mathrm{i}, \mathrm{t}} \beta+\rho_{\text {s.e. }} \mathbf{w}_{\mathrm{i}, \mathrm{t}-1}^{\text {Struc.Equiv. }} \mathbf{y}_{\mathrm{t}-1} \\
& +\beta_{v} \text { Veto }_{i, t-1}+\beta_{\text {inter }} \\
& \times\left(\text { Veto }_{i, t-1} \times \mathbf{w}_{\mathrm{i}, \mathrm{t}-1}^{\text {Struc.Equiv. }} \mathbf{y}_{\mathrm{t}-1}\right)+C_{i}+T_{t}+\varepsilon_{\mathrm{i}, \mathrm{t}}
\end{aligned}
$$

\section{Empirical Findings}

We ran models based on equation (2), and the results are reported in Table 2 . The first model specification reports the findings with regard to de jure domestic regulatory stringency (proxied by international treaty commitment). The second and third models report the findings regarding de facto policies measured by $\mathrm{SO}_{2}$ pollution intensity and BOD pollution intensity, respectively. Our focus here is to examine the effect of trade competition conditional on the different levels of veto players. In models with interaction terms, it is well known that not only the marginal effect but also the associated standard errors vary with the value of the other lower-order variable in the interaction term (Braumoeller 2004; Friedrich 1982). In other words, it is hard to get a sense of the conditional effects by looking at coefficients and standard errors only. In Figure 3, we show the marginal effects of trade competition on de jure and de facto environmental regulations, with the $95 \%$ confidence intervals, across different levels of domestic political constraints.

Figure 3 (a) shows the effects of trade competition on de jure regulatory stringency conditional on different levels of domestic veto player/political constraints. The long, dashed lines are the upper and 
Table 2 Mediating Effect of Domestic Institutions: Veto Players

\begin{tabular}{|c|c|c|c|c|c|c|}
\hline & \multirow{2}{*}{\multicolumn{2}{|c|}{$\begin{array}{c}\text { De Jure Policy } \\
\text { Treaty Commitment }\end{array}$}} & \multicolumn{4}{|c|}{ De facto Policy } \\
\hline & & & \multicolumn{2}{|c|}{$\mathrm{SO} 2$} & \multicolumn{2}{|c|}{ BOD } \\
\hline & Coef. & $\hat{\sigma}(p>|t|)$ & Coef. & $\hat{\sigma}(p>|t|)$ & Coef. & $\hat{\sigma}(p>|t|)$ \\
\hline Structural equivalence of trade & 0.004 & $0.012(0.76)$ & 0.024 & $0.009(0.01)$ & 0.052 & $0.015(0.00)$ \\
\hline Veto Player & -0.003 & $0.065(0.96)$ & -0.034 & $0.049(0.48)$ & -0.290 & $0.106(0.01)$ \\
\hline $\begin{array}{l}\text { Structural equivalence of } \\
\text { trade } \times \text { Veto Player }\end{array}$ & -0.001 & $0.019(0.98)$ & -0.024 & $0.019(0.22)$ & -0.056 & $0.021(0.01)$ \\
\hline Trade salience & -0.010 & $0.007(0.15)$ & -0.027 & $0.022(0.21)$ & 0.011 & $0.029(0.69)$ \\
\hline FDI stock ( $\%$ of GDP) & 0.013 & $0.002(0.00)$ & -0.016 & $0.005(0.00)$ & -0.020 & $0.006(0.00)$ \\
\hline GDP per cap & 0.030 & $0.084(0.72)$ & 0.810 & $0.235(0.00)$ & 0.666 & $0.299(0.03)$ \\
\hline GDP per cap ${ }^{2}$ & 0.000 & $0.005(0.97)$ & -0.060 & $0.015(0.00)$ & -0.050 & $0.018(0.01)$ \\
\hline Industry ( $\%$ of GDP) & 0.000 & $0.000(0.78)$ & 0.005 & $0.001(0.00)$ & 0.001 & $0.001(0.37)$ \\
\hline GDP growth & -0.000 & $0.000(0.18)$ & -0.005 & $0.001(0.00)$ & -0.005 & $0.001(0.00)$ \\
\hline Population density & 0.115 & $0.030(0.00)$ & 0.103 & $0.086(0.23)$ & -0.034 & $0.115(0.77)$ \\
\hline Urban population ( $\%$ of total) & 0.002 & $0.001(0.01)$ & 0.005 & $0.002(0.03)$ & 0.004 & $0.003(0.17)$ \\
\hline Intercept & 0.161 & $0.312(0.61)$ & -3.217 & $0.880(0.00)$ & -2.204 & $1.222(0.07)$ \\
\hline Lagged dependent variable & 0.688 & $0.011(0.00)$ & 0.737 & $0.011(0.00)$ & 0.790 & $0.018(0.00)$ \\
\hline Adjusted $R^{2}$ & & 0.992 & & 0.972 & & 0.948 \\
\hline N. of observations/Countries & & $2217 / 138$ & & $2212 / 138$ & & $1464 / 109$ \\
\hline
\end{tabular}

Country and year fixed effects not reported because of space limit.

lower bounds of the $95 \%$ confidence interval of the estimated effect of trade competition. The dark line in between the dashed lines represents the mean coefficient estimated. Figure 3 (a) suggests that regardless of the level of domestic political constraints, trade competition-measured as the weighted average of competitor countries' de jure regulatory stringencyhas no significant effect on a country's de jure regulatory stringency. This is consistent with our theoretical expectation: de jure environmental policy changes are explicit and policy makers are less likely to rewrite the laws, modify them, or insert new provisions to exempt certain industries from regulations.

Figure 3 (b) and Figure 3 (c) show the effect of trade competition on de facto changes in laws as reflected in pollution intensity. Figure 3 (b) shows the effects of trade competition on $\mathrm{SO}_{2}$ emission intensity, conditional on different levels of domestic veto player/political constraints. Figure 3 (b) suggests that when domestic political constraints are low, that is, lower than 0.3 in the $0-1$ Henisz political constraints scale, there is a significant relationship between trade competition and $\mathrm{SO}_{2}$ emission intensity. In other words, when domestic political constraints are low, policy makers are able to respond stealthily to trade competition which, all else equal, eventually is reflected in domestic pollution levels. The effect of trade competition, however, disappears when domestic political constraints reach a medium level $(>0.3)$. The density distribution of veto player data in Figure 1, however, shows that almost half of the observations in our data have a political constraints score lower than 0.3. Cases with a value of the political constraints variable around 0.3 include country-years such as India in 1981, Mexico between 1989 and 1991, and Jamaica between 1981 and 1983.

Figure 3 (c) reveals the pattern of the mediating effect of domestic veto players in water pollution intensity. Compared to Figure 3 (b), the effect of trade competition on water pollution can be observed for a relatively higher level of political constraints. Figure 3 (c) shows that the effect of trade competition is significant until the variable veto player/political constraints reach about 0.5. Thus, in relation to air pollution, the ability of citizen groups to block (de facto) policy changes requires a much higher institutional threshold for water pollution. For example, even if the ideological dispersion among policy makers is low (and/or number of veto players is low), citizen groups are able to block the de facto changes in air pollution. However, for water pollution, de facto policy changes may go through even when ideological dispersion is moderate (or midrange for the number of veto players). Cases with a value of the political constraints variable around 0.5 include country-years such as Argentina in 1993 and 2005, Bolivia in 1985-86 


\section{Figure 3 Testing the Effects of Trade Competition Conditional on the Levels of Domestic Political Constraints}

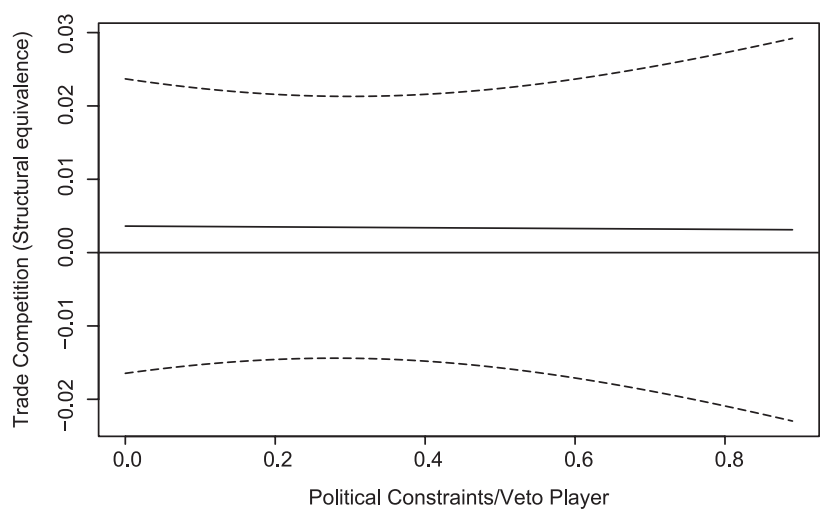

(a) Treaty commitment.

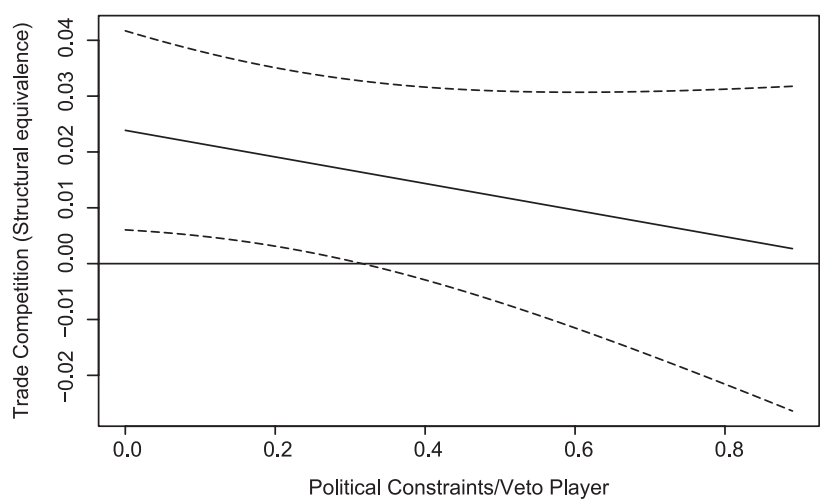

(b) SO2 pollution intensity.

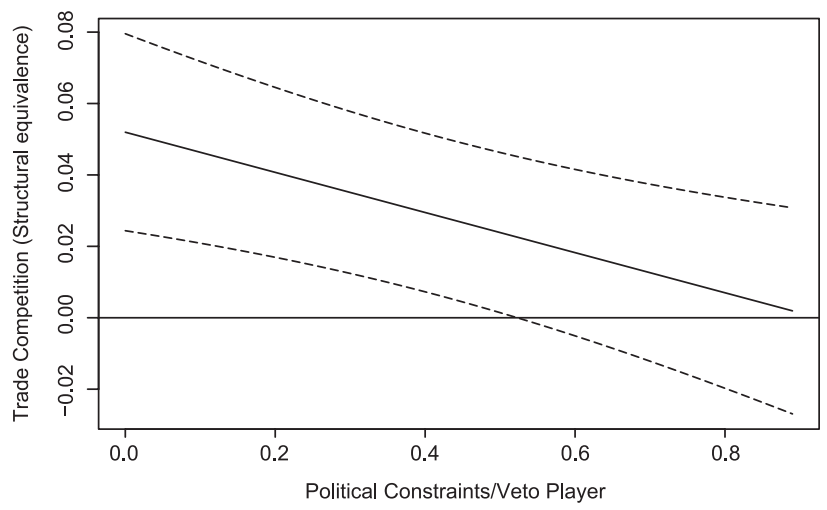

(c) BOD pollution intensity.

Note: The $\mathrm{x}$-axis is the changing value of political constraints. Y-axis represents the estimated spatial coefficient that captures the strength of trade competition. The dark line represent the mean coefficients estimated; long dashed lines are upper and lower bounds of $95 \%$ confidence interval of the estimated effects of trade competition. and 1995-98, and Israel between 1986 and 1992. The different cut-off points for air and water pollution intensity are, therefore, consistent with our theoretical expectations: because air pollution is a more visible issue than water pollution, it requires a lower threshold of political constraints to resist the same level of trade competitive pressure.

Regarding the effects of control variables, only FDI stock has a consistent and significant effect on both de jure and de facto stringency: higher level of FDI stock (as percentage of GDP) is associated with higher level of de jure regulatory stringency. It is also associated with higher level of de facto regulatory stringency as reflected in lower levels of air and water pollution intensity. Interestingly, trade salience consistently used in the trade-environment literature to test the general effect of globalization has no effect on de jure and de facto stringency. The inverted U-shape environmental Kuznets Curve is evident only for the de facto aspect of environmental regulation. Indeed, the turning points for air and water pollution intensity are around $\$ 854$ and $\$ 780$ in GDP per capita (in purchasing power parity), respectively, according to the coefficient estimates of GDP per capita and its square term. Industrial production (as a percentage of GDP) is associated with higher level of air pollution intensity only. ${ }^{31}$ While GDP growth rate is unrelated with de jure regulation stringency, it is negatively associated with both air and water pollution intensities. It seems that technological advancement and human capital accumulation brought by economic growth eventually induces lower pollution levels. Both population density and urban population (as a percentage of total population) are positively related to de jure regulatory stringency, not surprising given its importance for urban populations. ${ }^{32}$

\section{Conclusions and Implications}

This article makes several contributions to the study of policy diffusion and environmental politics. First,

\footnotetext{
${ }^{31}$ This makes intuitive sense because the largest share of $\mathrm{SO}_{2}$ emissions stems from stationary sources such as electricity generation, iron and steel industries, and transportation which are directly associated with industrialization; on the other hand, important sources of water pollution as measured by BOD often include sources that are not necessarily associated with industrialization such as urban sewage and agriculture wastes.

${ }^{32}$ Geography might affect pollution intensity. Literature suggests the influence of temperature, land area size, and population distribution on $\mathrm{CO}_{2}$ emission (Neumayer 2004). Our model includes country fixed effects to control for time invariant, cross-country heterogeneity including the geography.
} 
we suggest that international relations and comparative politics scholars need to go beyond comparing the explanatory power of the "second image" versus the "third image" variables. National level policy choices are shaped by both international and domestic pressures which often work in an interactive way. Scholars seeking to understand the effect of global or structural forces on domestic policies (what Gourevitch 1978 termed as "second image reversed") need to explicitly taken into account how domestic institutions might mediate such pressures.

Second, we highlight that the constraining influence of domestic institutions may vary even within subsets of a given policy domain, air and water pollution in our case. More broadly, to understand policy stability or change, scholars need to pay a closer attention to the interactions between actors and institutions. Institutionalist accounts of politics tend to pay less attention to how different actors employ the same institutional terrain leading to different policy outcomes. In relation to water pollution, the constraining influence of veto players is more pronounced for air pollution, a visible pollution issue around which organized, urban constituencies tend to mobilize. This finding might shed light on the underlying political processes in which different domestic groups compete to affect environmental policy. Institutions empower different constituencies which can impede or facilitate policy changes. Organized groups tend to have a greater influence on political institutions and therefore the policy processes. Mobilization of such groups critically depends on the extent to which they can appreciate how the proposed policy changes might hurt or benefit them and trample on or support their cherished beliefs. Governments are more likely to respond to pressures from trade competitors when they face fewer institutional constraints. The constraining effect of veto points can be observed earlier in the case of air pollution in relation to water pollution. Thus, institutions shape environmental policy but they matter in different ways within subsets of environmental issues, which reflect the pushback from different constituencies. Our article suggests looking beyond the broad categories such as "welfare policy" or "defence expenditure" because the politics of their subcomponents might vary.

Our research also suggests that scholars of policy change need to differentiate between de jure changes and de facto changes. While de jure changes are possible, they are less likely because they are visible and therefore reduce the information costs for interests groups to organize. Typically, momentous events which open the "policy window" allow policy makers to rewrite regulations (Baumgartner and Jones 1993; Kingdon 1984). In contrast, de facto changes are politically easier for policy makers and arguably more frequent. Thus, scholars seeking to study policy change and stability should extend their focus beyond de jure changes and carefully examine de facto changes as well.

Finally, our article also raises interesting questions for future research. For instance, our account of the role played by veto players focuses on the supply side of the policy change story. While we look at demand side of the story in terms of foreign trade pressures, future work can explore further about the domestic demand for environmental regulations including factors such as government ideology. Consistent with the existing literature, we have employed per capita income as a proxy for domestic demand for environmental protection. Future works should also explore measures such as public opinions and the strength of green parties. The World Value Survey suggests that at least in some wealthy developed countries, the percentage of people willing to sacrifice their income for environment protection has declined. For example, this percentage has dropped from $48.5 \%$ to $37.0 \%$ from 1990 to 1999 for Austria and from $62.8 \%$ to $57.0 \%$ between 1990 and 2000 for Canada (WVS 2009). In other words, the relationship between domestic demand for environmental protection and wealth needs to be carefully examined, instead of assumed. Moreover, we have argued that the influence of veto players is greater in the area of air pollution because of the greater visibility of air pollution compared to water pollution. However, to fully establish the fact that air pollution is more visible than water pollution, we need additional data. One way to establish this is by using cross-country public opinion data on visibility of different pollutants. While more research is certainly needed to better understand the intricate connections between trade, domestic political institutions, and environment, we hope this article has provided a solid foundation for this new and exciting area of future research.

\section{Acknowledgments}

Xun Cao's research was supported by a British Academy Small Grant (SG-54307) "Trade Competition, National Institutions, and Domestic Pollution." Previous versions of this article were presented at the Texas A\&M University, Pennsylvania State University, and the annual conferences of the International Political Economy Society and the American Political 
Science Association. We received valuable comments from Lee Ann Banaszak, Donna Bahry, Michael Bechtel, Scott Bennett, Gretchen Casper, Sean Ehrlich, Elisabeth Ellis, Robert Franzese, Matthew Golder, Sona Golder, Kim Hill, Hyeran Jo, Michael Koch, Vally Koubi, Suzanna Linn, Christine Lipsmeyer, Maria C. Escobar-Lemmon, Quan Li, David Lowery, Helen Milner, Bumba Mukherjee, Eric Neumayer, James Piazza, M.J. Peterson, James Rogers, Ken Scheve, Phil Schrodt, James Shortle, Michelle Taylor-Robinson, Ahmer Tarar, Guy Whitten, Dan Wood, Joseph Wright, other participants of the presentations, the JOP editors, and three anonymous reviewers. We want to especially thank Songying Fang, Vera Troeger, and Hugh Ward for valuable comments to improve the theoretical model.

\section{References}

Acemoglu, Daron, and Simon Johnson. 2005. "Unbundling Institutions." Journal of Political Economy 113 (5): 949-95.

Adolph, Christopher, Daniel M. Butler, and Sven E. Wilson. 2005. "Like Shoes and Shirt, One Size Does Not Fit All." Working paper. University of Washington, Stanford University, and Brigham Young University.

Alberini, Anna. 2001. "Environmental Regulation and Substitution between Sources of Pollution: An Empirical Analysis of Florida's Storage Tanks." Journal of Regulatory Economics 19 (1): 55-79

Antweiler, Werner, Brian R. Copeland, and M. Scott Taylor. 2001. "Is Free Trade Good for the Environment?" American Economic Review 91 (4): 877-908.

Baumgartner, F., and B. D. Jones. 1993. Agendas and Instability in American Politics. Chicago: University of Chicago Press.

Bernauer, Thomas, and Vally Koubi. 2009. "Effects of Political Institutions on Air Quality." Ecological Economics 68 (5): 1355-65.

Bluhm, Katharina. 2000. "East-West Integration and the Changing German Production Regime: A Firm-Centered Approach." Working Article 53 Program on Central and Eastern Europe, Harvard University.

Borgatti, Stephen P., and Martin G. Everett. 1992. "Notions of Position in Social Network Analysis." Sociological Methodology 22 (1): 1-35.

Braumoeller, Bear F. 2004. "Hypothesis Testing and Multiplicative Interaction Terms." International Organization 58 (4): 807-20.

Brooks, Sarah M. 2007. "When Does Diffusion Matter? Explaining the Spread of Structural Pension Reforms across Nations." Journal of Politics 69 (3): 701-15.

Brooks, Sarah M., and Marcus J. Kurtz. 2009. "Paths of Policy Diffusion: Institutional Legacies and the Diffusion of Capital Account Liberalization." Working Paper. The Ohio State University.

Broz, J. Lawrence, and Daniel Maliniak. 2010. "Malapportionment, Gasoline Taxes, and the United Nations Framework Convention on Climate Change." Presented at the 3rd Annual
Conference on The Political Economy of International Organizations, Georgetown University.

Bullard, Robert. 1991. Confronting Environmental Racism: Voices from the Grassroots. Boston: South End Press.

Burt, Ronald S. 1976. "Positions in Networks." Social Forces 55 (1): 93-122.

Cao, Xun, and Aseem Prakash. 2010. "Trade Competition and Domestic Pollution: A Panel Study, 1980-2003.” International Organization 64 (3): 481-503.

Cao, Xun, and Aseem Prakash. 2011. "Growing Exports by Signaling Product Quality: Trade Competition and the Cross-National Diffusion of ISO 9000 Quality Standards." Journal of Policy Analysis and Management 30 (1): 111-35.

de Soysa, Indra, and Eric Neumayer. 2005. "False Prophet or Genuine Saviour?” International Organization 59 (3): 731-72.

Daugsberg, Carsten, and Gert Tinggaard Svendsen. 2001. Green Taxation in Question: Politics and Economic Efficiency in Environmental Regulation. Basingstoke, UK: Palgrave.

Dolowitz, David P., and David Marsh. 2000. "Learning from Abroad: The Role of Policy Transfer in Contemporary PolicyMaking." Governance 13 (1): 5-24.

Doner, Richard F., Bryan K. Ritchie, and Dan Slater. 2005. "Systemic Vulnerability and the Origins of Developmental States: Northeast and Southeast Asia in Comparative Perspective." International Organization 59 (2): 237-361.

Drezner, Daniel 2001. "Globalization and Policy Convergence." International Studies Review 3 (1): 53-78.

Elkins, Zachary, Andrew T. Guzman, and Beth A. Simmons. 2006. "Competing for Capital: The Diffusion of Bilateral Investment Treaties, 1960-2000.” International Organization 60 (4): 811-46.

Ehrlich, Sean D. 2009. "Why Are Some Democracies Greener than Others? An Access Point Theory of Domestic Institutions and Environmental Regulations." Working Paper. Florida State University.

Elkins, Zachary, and Beth A. Simmons. 2005. "On Waves, Clusters, and Diffusion: A Conceptual Framework." The Annals of the American Academy of Political and Social Science 598 (1): 33-51.

Fiorino, Daniel J. 2006. The New Environmental Regulation. Cambridge, MA: MIT Press.

Franzese, Robert, and Jude C. Hays. 2006. "Spatial-Econometric Models of Cross-Sectional Interdependence in PoliticalScience Panel and Time-Series-Cross-Section Data." Political Analysis 15 (2): 140-64.

Franzese, Robert, and Jude C. Hays. 2008. "Interdependence in Comparative Politics: Substance, Theory, Empirics, Substance." Comparative Political Studies, 40th Anniversary Issue: Frontiers of Comparative Politics 41 (4/5): 742-80.

Fredriksson, Per G., John A. List, and Daniel L. Millimet. 2004. "Chasing the Smokestack: Strategic Policymaking with Multiple Instruments." Regional Science and Urban Economics 34 (4): 387-410.

Friedrich, Robert J. 1982. "In Defense of Multiplicative Terms in Multiple Regression Equations." American Journal of Political Science 26 (4): 797-835.

Frye, Timothy, and Edward Mansfield. 2004. "Timing is Everything: Elections and Trade Liberalization in the Postcommunist World." Comparative Political Studies 37 (4): 371-98.

Gamper-Rabindran, S.. 2006. "Did the EPA's Voluntary Industrial Toxics Program Reduce Emissions? A GIS Analysis of Distributional Impacts and By-Media Analysis of Substitution." 
Journal of Environmental Economics and Management 52 (1): 391-410.

Ganghof, Steffen. 2003. "Promises and Pitfalls of Veto Player Analysis." Swiss Political Science Review 9 (2): 1-25.

Garrett, Geoffrey. 1998. Partisan Politics in the Global Economy. New York: Cambridge University Press.

Geddes, Barbara. 1994. Politicians Dilemma: Building State Capacity in Latin America. Berkeley, CA: University of California Press.

Gilardi, Fabrizio. 2005. “The Institutional Foundations of Regulatory Capitalism: The Diffusion of Independent Regulatory Agencies in Western Europe." The ANNALS of the American Academy of Political and Social Science 598 (1): 84-101.

Gourevitch, Peter. 1978. "The Second Image Reversed: The International Sources of Domestic Politics." International Organization 32 (4): 881-911.

Gray, Wayne B., and Ronald J. Shadbegian. 1995. "Pollution Abatement Costs, Regulation, and Plant-Level Productivity." NBER Working Paper 4994. Clark University.

Greenhill, Brian, Layna Mosley, and Aseem Prakash. 2009. "Trade and Labor Rights: A Panel Study, 1986-2002." American Political Science Review 103 (4): 669-90.

Guler, Isen, Mauro Guillen, and John Muir MacPherson. 2002. "Global Competition, Institutions, and Organizational Change: The International Diffusion of the ISO 9000 Quality Standards." Administrative Science Quarterly 47 (2): 207-32.

Hanneman, Robert A., and Mark Riddle. 2005. "Introduction to Social Network Methods." Riverside: University of California, Riverside. http: //faculty.ucr.edu/ hanneman/.

Henisz, Witold J. 2002. "The Institutional Environment for Infrastructure Investment." Industrial and Corporate Change 11 (2): 355-89.

Jaffe, Adam, Steven Peterson, Paul Portney, and Robert Stavins. 1995. "Environmental Regulation and the Competitiveness of U.S. Manufacturing." Journal of Economic Literature 33 (1): 132-63.

Jo, Hyeran. 2009. "Diffusion of International Accounting Standards: Domestic-International Linkage." Presented at the Annual Convention of the International Studies Association, New York.

Kerner, Andrew, and Jeffrey Kucik. 2010. "The International and Domestic Determinants of Insider Trading Laws." International Studies Quarterly 54 (3): 657-82.

Kingdon, J. 1984. Agendas, Alternatives, and Public Policies. New York: HarperCollins.

Kiviet, Jan F. 1995. "On Bias, Inconsistency, and Efficiency of Various Estimators in Dynamic Panel Data Models." Journal of Econometrics 68 (1): 53-78.

Klingemann, Hans-Dieter, Andrea Volkens, Judith Bara, and Ian Budge (2006) Mapping Policy Preferences II: Estimates for Parties, Electors and Governments in Central and Eastern Europe, European Union and OECD 1990-2003. Oxford: Oxford University Press.

Konisky, David M. 2007. "Regulatory Competition and Environmental Enforcement: Is There a Race to the Bottom?" American Journal of Political Science 51 (4): 853-72.

Lake, David A., and Robert Powell. 1999. Strategic Choice and International Relations. Princeton, NJ: Princeton University Press.

Lee, Chang Kil, and David Strang. 2006. "The International Diffusion of Public-Sector Downsizing: Network Emulation and Theory-Driven Learning." International Organization 60 (4): 883-909.
Levi-Faur, David. 2005. "The Global Diffusion of Regulatory Capitalism." The ANNALS of the American Academy of Political and Social Science 598 (1): 12-32.

Li, Quan, and Rafael Reuveny. 2006. "Democracy and Environmental Degradation." International Studies Quarterly 50 (4): 935-56.

Mahutga, Matthew C. 2006. "The Persistence of Structural Inequality? A Network Analysis of International Trade, 1965-2000." Social Forces 84 (4): 1863-89.

Mansfield, Edward D., Helen V. Milner, and Jon C. Pevehouse. 2008. "Democracy, Veto Players and the Depth of Regional Integration." World Economy 31 (1): 67-96.

Massey, Douglass, and Nancy Denton. 1993. American Apartheid. Boston: Cambridge, MA: Harvard University Press

Murdoch, James C., Todd Sandler, and Keith Sargent. 1997. “A Tale of Two Collectives: Sulphur versus Nitrogen Oxides Emission Reduction in Europe.” Economica 64 (254): 281-301.

Neumayer, Eric. 2002. "Do Democracies Exhibit Stronger International Environmental Commitment? A Cross-Country Analysis." Journal of Peace Research 39 (2): 139-64.

Neumayer, Eric. 2003. "Are Left-Wing Party Strength and Corporatism Good for the Environment? Evidence from Panel Analysis of Air Pollution in OECD Countries." Ecological Economics 45 (2): 203-20.

Neumayer, Eric. 2004. "National Carbon Dioxide Emissions: Geography Matters.” Area 36 (1): 33-40.

North, Douglas. 1990. Institutions, Institutional Change and Economic Performance. Cambridge, MA: Cambridge University Press.

Ostrom, Elinor. 1990. Governing the Commons: The Evolution of Institutions for Collective Action. Cambridge, MA: Cambridge University Press.

Polillo, Simone, and Mauro F. Guillen. 2005. "Globalization Pressures and the State: The Worldwide Spread of Central Bank Independence.” American Journal of Sociology 110 (6): 1764-1802.

Porter, Michael E., and Class van der Linde. 1995. "Toward a New Conception of the Environment-Competitiveness Relationship." Journal of Economic Perspectives 9 (4): 97-118.

Prakash, Aseem, and Matthew Potoski. 2006. "Racing to the Bottom? Globalization, Environmental Governance, and ISO 14001." American Journal of Political Science 50 (2): 347-61.

Rudra, Nita. 2002. "Globalization and the Decline of the Welfare State in Less-Developed Countries." International Organization 56 (2): 411-45.

Scruggs, Lyle A. 1999. "Institutions and Environmental Performance in Seventeen Western Democracies." British Journal of Political Science 29 (1): 1-31.

Sigman, Hilary. 1996. "Cross-Media Pollution: Responses to Restrictions on Chlorinated Solvent Releases." Land Economics 72 (3): 298-312.

Simmons, Beth A., Frank Dobbin, and Geoffrey Garrett. 2006. "Introduction: The International Diffusion of Liberalism." International Organization 60 (4): 781-810.

Stern, David I. 2005. "Global Sulfur Emissions from 1850 to 2000." Chemosphere 58 (2): 163-75.

Tews, Kerstin, Per-Olof Busch, and Helge Jorgens. 2003. "The Diffusion of New Environmental Policy Instruments." European Journal of Political Research 42 (4): 569-600.

Thelen, Kathleen. 2001. "Varieties of Labor Politics in the Developed Democracies." In Varieties of Capitalism, ed. Peter Hall and David Soskice. Oxford: Oxford University Press, 71-104. 
Tsebelis, George. 1995. "Decision Making in Political Systems: Veto Players in Presidentialism, Parliamentalism, Multicameralism, and Multipartyism." British Journal of Political Science 25 (July): 289-326.

Tsebelis, George. 1999. "Veto Players and Law Production in Parliamentary Democracies: An Empirical Analysis." American Political Science Review 93 (3): 591-608.

Ward, Hugh, and Xun Cao. Forthcoming. "Domestic and International Influences on Green Taxation." Comparative Political Studies.

Way, Christopher R. 2005. "Political Insecurity and the Diffusion of Financial Market Regulation." The ANNALS of the American Academy of Political and Social Science 598 (1): 125-44.

Weyland, Kurt Gerhard. 2005. "Theories of Policy Diffusion: Lessons from Latin American Pension Reform." World Politics 57 (2): 262-95.

WVS. 2009. "World Values Survey, 1981-2008, Official Aggregate v.20090901.” World Values Survey Association. Aggregate File Producer: ASEP/JDS, Madrid.
World Bank. 2008. World Development Indicators. Available at: http: //data.worldbank.org/data-catalog (accessed 11 February 2008).

York, Richard, Eugene Rosa, and Thomas Dietz. 2003. "Footprints on the Earth: The Environmental Consequences of Modernity." American Sociological Review 68 (2): 279-300.

Xun Cao is Assistant Professor at the Department of Political Science, Penn State University, University Park, PA 16802.

Aseem Prakash is Professor of Political Science and the Walker Family Professor for the College of Arts and Sciences, University of Washington, Seattle, Washington 98195-3530. 